\title{
Adapting feeding methods for less nitrogen pollution from pig and dairy cattle farming: abatement costs and uncertainties
}

\section{Magdalena Pierer, Barbara Amon \& Wilfried Winiwarter}

Nutrient Cycling in Agroecosystems (formerly Fertilizer Research)

ISSN 1385-1314

Nutr Cycl Agroecosyst

DOI 10.1007/s10705-016-9767-0
Volume 104/1 January 2016

ONLINE FIRST

Nutrient Cycling

in

Agroecosystems

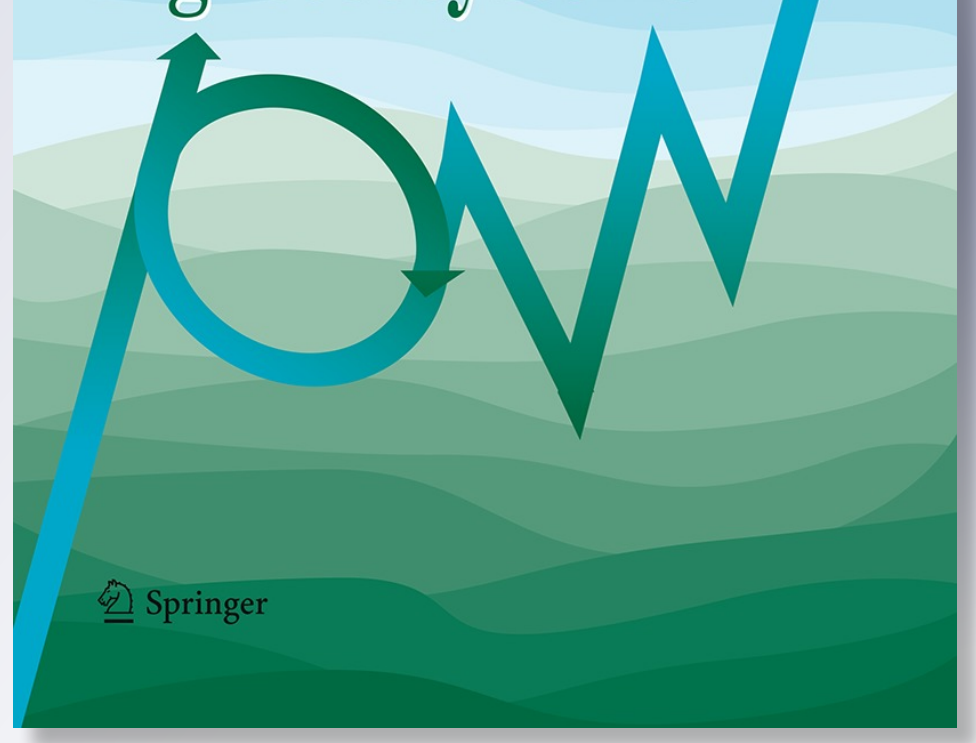

包 Springer 
2 Adapting feeding methods for less nitrogen pollution from pig and 3 dairy cattle farming: Abatement costs and uncertainties

Authors: Magdalena Pierer ${ }^{a,}$, Barbara Amon $^{\mathrm{b}}$, Wilfried Winiwarter ${ }^{c}$ a Institute of Systems Sciences, Innovation and Sustainability Research, University of Graz, Merangasse 18, $8010 \mathrm{Graz}$, Austria

b Leibniz Institute for Agricultural Engineering Potsdam-Bornim, Department Technology Assessment and Substance Cycles, Max-Eyth-Allee 100, 14469 Potsdam, Germany

C International Institute for Applied Systems Analysis (IIASA), Schlossplatz 1, 2361 Laxenburg, Austria

* corresponding author at: Merangasse 18, 8010 Graz, Austria. E-mail: magdalena.pierer@edu.uni-graz.at. Tel.: +43 (0)316 380 - 7340

\section{Acknowledgements}

This paper is a contribution to the International Nitrogen Initiative. It takes advantage of the results of the FarmClim project funded by the Austrian Climate Research Programme (ACRP). scholarship received from the University of Graz. 
 \\ Adapting feeding methods for less nitrogen pollution from pig and dairy}

\section{cattle farming: Abatement costs and uncertainties}

\section{Abstract}

This study assesses abatement costs of three measures aimed at reducing nitrogen (N)

emissions from livestock production: protein-adjusted feeding strategies for pigs, and

30 higher-quality forage for dairy cattle. In a partial cost approach, we quantified the effect of different measures on $\mathrm{N}$ losses and production costs. We accounted for emissions of $\mathrm{NH}_{3}$, $\mathrm{N}_{2} \mathrm{O}$ and $\mathrm{NO}$ from animal housing, manure storage, manure application, and from soils. Uncertainties related to volatile prices and assumptions about excretion rates and emission factors were assessed in a Monte Carlo simulation. Covering variability of individual input parameters, this uncertainty assessment addresses a fundamental gap in current decision support on $\mathrm{N}$ loss reduction measures. For the scenarios investigated, average $\mathrm{N}$ abatement costs at farm level were negative and represented net benefits to farmers: In pig husbandry, adapting feeding practices in most individual situations resulted in net benefits, both for three-phase feeding [min -35 , max +5 , mean $-14 € / \mathrm{kg} \mathrm{N}$ abated] and optimised single-phase feeding [min $-52, \max +4$, mean $-21 € / \mathrm{kg} \mathrm{N}$ abated]. In dairy production, $\mathrm{N}$ abatement by improved forage quality proved invariably more economic than current practice [min -40 , max -11 , mean $-21 € / \mathrm{kg} \mathrm{N}$ abated]. As shown in this study, $\mathrm{N}$ abatement costs can serve as a framework for comparing the cost-effectiveness and feasibility of $\mathrm{N}$ loss reduction measures within and between livestock production systems. This is in turn critical when informing practitioners and providing policy support on workable strategies for reducing the $\mathrm{N}$ footprint of animal husbandry.

Keywords: nitrogen losses, nitrogen abatement cost, Monte Carlo simulation, nitrogen use efficiency (NUE), pig fattening, dairy forage 
50 Human influence on the global nitrogen $(\mathrm{N})$ cycle is substantial, with agriculture as the 51 largest contributor. Reactive $\mathrm{N}$ refers to those chemical forms of $\mathrm{N}$ that are available to plants and animals. Variable proportions of the reactive $\mathrm{N}$ used as fertiliser for feed crop production are eventually released back into the environment during the storage and decomposition of animal manures. Inefficient manure management practices and excessive application rates increase emissions of reactive $\mathrm{N}$, with a range of detrimental effects on ecosystems, human health and global climate (Erisman et al. 2013; Fowler et al. 2013; Galloway et al. 2004; Galloway et al. 2008). In response to these challenges, which apply particularly to intensive, industrialized production systems, a broad range of measures has been proposed for different agricultural sectors to become more nitrogen-efficient. In arable farming, cover crops and optimised low- $\mathrm{N}$ fertilisation have proven effective at reducing $\mathrm{N}$ losses (Dalgaard et al. 2014; Döhler et al. 2011; Newell Price et al. 2011; Reis et al. 2015). For animal husbandry effective $\mathrm{N}$ loss reduction has been demonstrated for instance for optimised livestock feeding and for improved manure management (i.e. removal, storage, and spreading techniques) (Dalgaard et al. 2014; Döhler et al. 2011; Newell Price et al. 2011; Reis et al. 2015; Rotz 2004). Animal nutrition has been highlighted as a priority area for reducing environmental $\mathrm{N}$ pollution from livestock production (Aarnink and Verstegen 2007; Klimont and Brink 2004). Increasing the $\mathrm{N}$ use efficiency (NUE) of common husbandry systems by adapting feeding methods is therefore the focus of this paper.

In pig farming, feeding practices can be adapted to minimise $\mathrm{N}$ excretion and $\mathrm{N}$ losses from manure management by phase feeding, i.e. adjusting feed composition according to the pig's physiological needs at different growth stages; supplementing diets with limiting amino acids; reducing crude protein intake; and shifting $\mathrm{N}$ excretion from urine to faeces by 
adjusting feed composition (Aarnink and Verstegen 2007; Dourmad and Jondreville 2007;

74 Jongebreur et al. 2005; Nahm 2002; van Vuuren et al. 2015).

Under production conditions in industrialised countries, reducing $\mathrm{N}$ intake by dairy cattle has the potential to decrease $\mathrm{N}$ excretion and $\mathrm{N}$ losses without compromising milk production (Bittman et al. 2014; Powell 2014). One approach to reducing emissions of reactive $\mathrm{N}$ and greenhouse gases (GHG) from dairy cattle farming is to increase milk yields to an extent that outweighs additional $\mathrm{N}$ excretion. This can be achieved by enhancing the energy density of the feed, e.g. through a higher content of grain-concentrates in compound feeds or higherquality forage (Gruber et al. 1999; Hörtenhuber et al. 2010; Ryan et al. 2011). However, the effect of more concentrate might be partially counteracted by additional emissions from soils and fertiliser use in the production of such feeds (Hörtenhuber et al. 2010). This approach also raises questions regarding animal health as well as ethical concerns, since the capacity of dairy cows to digest concentrates is limited, and using grains as livestock feed rather than for human nutrition is questionable (Ertl et al. 2014; Hörtenhuber et al. 2011). To address these concerns, Hörtenhuber et al. (2010) proposed to focus efforts on finding alternative ways to improve the nutrient and energy density of forage. One measure which can achieve this, while avoiding the dilemma of grain-based feeds, is to increase the number of grass cuts per year (Gruber et al. 1999; Gruber and Pötsch 2006).

Using $\mathrm{N}$ inefficiently by excess feeding to livestock not only contributes to environmental pollution via increased $\mathrm{N}$ excretion; expenses for surplus feed also unnecessarily increase costs to farmers. Feed costs generally account for a large proportion of total costs of animal production (Finneran et al. 2012; Powell et al. 2013). Many studies focus on possible reductions of negative environmental effects, without consistently considering the economic viability of those measures at farm level (Aarnink and Verstegen 2007; Dourmad and 
Jondreville 2007; Nahm 2002; Ryan et al. 2011). Other studies analyse economic effects of different feeding strategies and strive for economic optimisation, but lack detailed discussion of environmental implications (Finneran et al. 2012; Marston et al. 2011; Niemi et al. 2010; Vibart et al. 2012). Discussions which examine and synthesise both aspects, i.e. the potential environmental benefits and the economic implications of different measures, are scarce (see e.g. van Vuuren et al. (2015) who review the economics of low-N feeding strategies). Such analyses, however, are vital for setting policy priorities: A given $\mathrm{N}$ abatement measure will appear more attractive to farmers, and will thus more likely be adopted, if there is evidence supporting its economic feasibility and benefits. On the other hand, if the reduction of $\mathrm{N}$ emissions is not profitable for farmers under current conditions, 108 uptake.

109 The recently completed Austrian research project FarmClim - "Farming for a better climate" (Amon et al. 2014) aimed to identify cost-effective and practical strategies for farmers to 111 increase the nitrogen-efficiency and to reduce the GHG emissions of their production 112 systems. Measures considered for animal husbandry included phase feeding for pigs, 113 improved dairy cattle diets, and anaerobic digestion of animal manures. For crop production, 114 increasing the use of legumes in crop rotations, and optimising fertiliser input were 115 addressed. In close collaboration between stakeholders (researchers as well as agricultural 116 institutions and extension services) agricultural measures were assessed and discussed from 117 different perspectives in a transdisciplinary and participatory process. The livestock part of 118 FarmClim focussed in particular on the situation of farmers, as a central aim was to provide 119 practical guidance at farm level. 
The objective of the present paper is to assess farm-level $\mathrm{N}$ abatement potentials and costs of three key measures developed for animal husbandry in the FarmClim project (Amon et al. 2014): optimised single phase feeding and three-phase feeding for pigs, and higher-quality forage for dairy cattle. A Monte Carlo uncertainty analysis was conducted to account for uncertainties due to volatility in demand and market prices as well as for variability in milk yield, $\mathrm{N}$ excretion and $\mathrm{N}$ emissions. Reducing the dependency on specific assumptions of input data, this uncertainty analysis enables the consideration of a broader range of production characteristics. We first calculated partial gross margins per unit of product and then derived changes in gross margins between different measures, by comparing additional costs and benefits at farm level. In order to estimate average $\mathrm{N}$ abatement costs for each of the measures, we assessed potential reductions in $\mathrm{N}$ excretion and in the subsequent volatilisation of $\mathrm{NH}_{3}, \mathrm{~N}_{2} \mathrm{O}$ and $\mathrm{NO}$.

\section{Methods}

\subsection{Scope of analysis}

This study addresses exemplary, individual pig and dairy farms, aiming to provide information for decision making in practice. Therefore cost analyses focus on private costs and benefits for farmers. Calculating average abatement costs for specific measures, we did not assess abatement potentials for the entire sector of agriculture nationally or internationally. Furthermore, because individual farms are considered as price takers within the market, complex market dynamics, such as the consequences of many farmers changing their activities, were not accounted for within this study. Likewise, sectoral, national or international developments and interactions are neglected. In line with this farm perspective, only those emissions related directly to the farming practice were assessed (i.e., 143 animal housing and manure management). 
Based on some assumptions about principal production traits that are in line with EU

averages (see below for details), we were able to simulate a wide of range of production situations by independently and simultaneously varying several input variables in a Monte Carlo analysis (e.g. feed and product prices, $\mathrm{N}$ excretion rates, $\mathrm{N}$ emission factors). Data were sourced from agricultural extension services and guidelines, such as: the Austrian Federal Institute of Agricultural Economics (AWI 2015) for production traits and related costs, national statistical information from Statistics Austria (2014) mainly for input and output prices, and international guidelines for $\mathrm{N}$ excretion and emission factors (European Environment Agency (EEA) 2013; IPCC 2006a). Specific data used can be found in Table A.3 in the Annex. Additional input data were taken from the FarmClim project (Amon et al. 2014; Moser et al. 2013), and were further processed as detailed in the subsequent section.

\subsection{N abatement through optimised diets: Measures and data}

Pigs. Phase feeding systems adjust the diet in several phases, rather than providing feed of unchanged composition over the entire course of the fattening period. More specifically, the supply of protein as the main source of dietary $\mathrm{N}$ is matched to the changing physiological needs of the pig, thereby reducing excess supply and excretion of $\mathrm{N}$. As the optimum dietary protein concentration decreases during the growth of a pig, phase feeding reduces $\mathrm{N}$ emissions without compromising growth performance (i.e. slaughter weight) (Dämmgen et al. 2011; Pomar et al. 2014; van Vuuren et al. 2015).

Phase feeding systems usually require additional investment in feeding technology. Such 164 investment is only economically feasible for farms with a sufficiently long-term production perspective and economies of scale in cost savings. For farms with shorter planning horizons, optimisation measures that require upfront investment are often disproportionate to profit margins and hence not an option. That situation is faced by many small farms across Europe; 
especially family farmers may not know whether their operations will be continued after their retirement. For such farms, a technologically simpler and more attractive option would be to optimise the feed mix in a traditional single-phase feeding system by reducing the overall protein content of the diet. This approach is generally less effective at reducing $\mathrm{N}$ losses than phase feeding. Nevertheless, we included optimised single-phase feeding in this analysis as it was the aim of our research to find $\mathrm{N}$ abatement methods that would be workable more generally in Europe.

For both pig feeding methods, it is important to bear in mind that reduced protein intake necessitates the supplementation of limiting essential amino acids. The resulting costs were included in our calculations.

We analysed the following scenarios for pig fattening (Table 1):

- a single-phase feeding system as the reference case (REF_pig),

- an optimised single-phase feeding system with reduced dietary crude protein content but supplementation of synthetic amino acids (S1_pig), and

All three scenarios were based on a total feed intake of $254 \mathrm{~kg}$ per fattening pig and a slaughter weight of $96 \mathrm{~kg}$ (AWI 2015). Thus, whereas the feed composition changes, the pigs' performance level remains constant. The production system was further characterised by a herd size of 450 fattening places with a turnover rate of 2.67 , and an $\mathrm{N}$ excretion rate of 10.3 kg N per fattening place and year (AWI 2015; Umweltbundesamt 2014b). While this is based on Austrian sources to maintain internal consistency, the basic characteristics are in line with average EU values (see table A.1 in the Annex for information on $\mathrm{N}$ excretion and slaughter 191 weight). 
[Insert Table 1 here]

Dairy cattle. Forage quality can be improved by cutting grassland more frequently (Gruber et al. 1999). This results in a lower total dry matter yield of the cut grass, but at the same time increases forage intake, digestibility and protein content (Gruber et al. 1999; Gruber and Pötsch 2006). The higher protein content leads to increases in total $\mathrm{N}$ intake and $\mathrm{N}$ excretion, which seems to counteract the intended reduction of $\mathrm{N}$ losses at first sight. However, the larger amount of energy provided by higher-quality forage supports higher milk yields, and thereby reduces $\mathrm{N}$ excretion per $\mathrm{kg}$ milk produced (Ertl et al. 2014; Steinwidder and Guggenberger 2003). For dairy cattle, we analysed two feeding options: a reference case (REF_milk) with medium-quality forage from three grass cuts per year and a mixture of concentrate feed; and a scenario with high-quality forage (S_milk), where the frequency of grass cuts was increased to four. This results in a higher intake of grass-silage and hay. Due to the conceptual assumption of a constant share of each forage component in the total diet (i.e., $65 \%$ grass silage, $20 \%$ maize silage, $15 \%$ hay), intake of maize silage is also increased. In addition, S_milk included the same ration of concentrate feed as REF_milk (see Table 2). In contrast to the pig scenarios, both feed intake and performance (i.e., milk yield) are affected by the measure. We assumed predominantly grass-based diets with limited supplementation of concentrate feed, and local climatic conditions that allow for frequent grass-cutting and correspondingly high forage quality. We assumed baseline milk yield (6500 $\mathrm{kg} / \mathrm{cow} /$ year) and $\mathrm{N}$ excretion (100 kg N/cow/year) to correspond to the EU-28 average (6538 kg milk/cow/year and $108.07 \mathrm{~kg} \mathrm{~N} / \mathrm{cow} /$ year, respectively; see Table A.2 in the Annex for country data). Our calculation of attainable milk yield was based on following assumptions: From their diet, dairy cattle need to obtain $13870 \mathrm{MJ}$ worth of net energy for lactation (NEL) for maintenance, and an additional $700 \mathrm{MJ}$ NEL during the preparation phase 
for lactation. That latter phase hence requires a more energy-dense diet, i.e. one with a

217 larger concentrate component. Any further energy intake is available for milk production, where 3.3 MJ NEL are required for each kg of milk produced (AWI 2015).

[Insert Table 2 here]

\section{$220 \quad$ 2.3. Nitrogen abatement}

221 Nitrogen abatement is defined as the total amount of $\mathrm{N}$ emissions that can be avoided by 222 implementing a given measure, in comparison to the reference case. To quantify these

"avoided losses" of $\mathrm{N}$ to the environment, emissions of ammonia $\left(\mathrm{NH}_{3}\right)$, nitrous oxide $\left(\mathrm{N}_{2} \mathrm{O}\right)$ and nitric oxide (NO) were derived from $\mathrm{N}$ excretion rates and emission factors. Thus, the terms "N emission" (or "N losses") and "N abated" in this paper always refer to the sum of emissions of these three $\mathrm{N}$ species. Emission sources considered here were animal housing and manure management (storage and application to land including direct emissions from soil) (IPCC 2006a). The analysis hence incorporated the entire chain of $\mathrm{N}$ emissions which arise from livestock production and which are directly attributable to individual farms. Upstream effects, e.g. of feed or fuel production, which would typically be included in life cycle analyses (LCA), were not considered in this study.

$\mathrm{N}$ emissions for both reference cases (REF_pig and REF_milk), as given in Table A.3 in the Annex, were based on excretion rates and emission factors from Austria's national emission inventory reports (Umweltbundesamt 2014a, 2014b), on a regression model predicting dairy cow excretion (Gruber et al. 1999), and on international guidance documents (European Environment Agency (EEA) 2013, IPCC 2006a, 2006b). Our calculations further assumed the use of a liquid slurry system for manure management in all scenarios.

The reduction of ammonia emissions due to adjustments in feeding methods has been assessed in a range of experimental studies (Aarnink and Verstegen 2007; Dämmgen et al. 
2011; Dourmad and Jondreville 2007; Pomar et al. 2014). Those studies provide a valuable

baseline. However, due to the number of variables and lack of standards for experimental conditions, results are often only valid for very specific technical and geographical contexts. This unfortunately limits the extent to which those empirical studies can inform policy and practice elsewhere. For the same reasons, our calculations did not draw upon results from individual experimental studies. We instead took a simplified approach for approximating the change in $\mathrm{N}$ excretion:

247 For pigs, the reduction in $\mathrm{N}$ excretion can be derived from simple $\mathrm{N}$ balance considerations: 248 When excess $\mathrm{N}$ supply in pig fattening diets is reduced (as described above), a given 249 decrease in protein intake directly translates into a corresponding decrease in $\mathrm{N}$ excretion 250 (Kornegay and Harper 1997). N emissions then decline accordingly, as they are calculated as 251 percentages of $\mathrm{N}$ excretion.

252 In dairy systems, estimating $\mathrm{N}$ abatement is more complex: When milk yield is increased by 253 raising the protein density of the diet, this inherently also increases $\mathrm{N}$ excretion. However, it 254 is generally assumed that the resulting increase in $\mathrm{N}$ emissions is outweighed by the higher 255 milk yields. National inventory reports (Umweltbundesamt 2014b) for instance estimate $\mathrm{N}$ 256 emissions with a linear function, where $\mathrm{N}$ excretion exclusively depends upon milk yields. In 257 reality, $\mathrm{N}$ excretion however also depends, among other factors, on the protein content of 258 the diet (Gruber and Pötsch 2006; Pötsch 2006). Gruber et al. (1999) have developed a more 259 detailed regression model, which predicts manure $\mathrm{N}$ concentrations and $\mathrm{N}$ excretion of dairy 260 cows, based on forage and concentrate intake and on the corresponding crude protein and 261 energy content of the diet. Their model was used here to estimate $\mathrm{N}$ excretion more 262 accurately (Eq.1) (Gruber et al. 1999):

$$
E c_{N}=-0.6+0.106\left(I F * X P_{F}\right)+1.153\left(I C * N E L_{C}\right)+0.0605\left(X P_{T} * N E L_{T}\right)
$$


where: $\mathrm{EC}_{\mathrm{N}}=$ excretion of $\mathrm{N}$ per cow $(\mathrm{g} /$ day); $\mathrm{IF}=$ intake of forage $(\mathrm{kg} \mathrm{DM}) ; \mathrm{IC}=$ intake of concentrate $(\mathrm{kg} \mathrm{DM})$; $X P_{F}, X P_{T}=$ crude protein concentration of forage and total ration $(g / k g D M) ; N E L c, N E L T=$ energy concentration of the concentrate and total ration (MJ/kg DM)

\subsection{Cost calculation}

When comparing the economic feasibility of different management practices, the most relevant changes in costs and benefits are those that directly result from the implementation of the measures in question. Standard costs of equipment, etc., can thus be omitted if they are constant (Rejesus and Hornbaker 1999; Ryan 2005). This simplifies the calculation and eliminates a source of bias and uncertainty, without compromising the validity and explanatory power of the results. While this partial cost approach has been criticised (Finneran et al. 2012), it is appropriate for the study at hand, as the purpose here was to assess costs and benefits of $\mathrm{N}$ abatement in relation to a certain reference situation, rather than determine general farm profitability, for which full cost accounting would have been required. In this vein, we did not quantify opportunity, follow-up or indirect costs and interactions, which are important elements for overall farm profitability assessments, but are not generally considered in gross margin calculations.

To reflect the private costs and benefits of different $\mathrm{N}$ abatement measures at farm level, we calculated partial gross margins (PGM) per unit of product, i.e. per kg meat or milk, for each feeding scenario. PGM was defined as revenues minus costs of production per unit sold. (N.B.: Costs must be directly related to the abatement measure). Partial gross margins hence represent the revenues available for covering the remaining costs which were unaffected by the measure, and to generate profit. The following costs were included: costs of the feed components, investment in phase feeding systems for S2_pig, and additional costs due to more frequent cutting for S_milk. These latter costs have been incorporated in the costs of forage provision and encompass seeds, fertilizer, crop protection, variable machinery costs, 
and labour costs. Revenues came from selling pork and milk at market prices. We ignored potential grants, subsidies, and any costs not practically related to the $\mathrm{N}$ abatement measures. Table A.3 in the Annex lists the specific data and references used, and equations 2 and 3 outline the calculation of gross margins for pig and milk production, respectively.

$$
\pi_{p i g}=\frac{1}{W}\left(p_{p i g} * W-\sum p f_{i} * F_{i}-c_{\text {invest }}\right)
$$

292 Where: $\pi_{\text {pig }}=$ partial gross margin per $\mathrm{kg}$ pork $[€ / \mathrm{kg}] ; \mathrm{W}=$ slaughter weight of pig $[\mathrm{kg}] ; p_{\text {pig }}=$ price of pork $293[€ / \mathrm{kg}] ; \mathrm{pf}_{\mathrm{i}}=$ price of feed component $i[€ / \mathrm{kg}] ; \mathrm{F}_{\mathrm{i}}=$ intake of feed component $i[\mathrm{~kg} / \mathrm{pig} /$ year $] ;$ cinvest $=$ investment cost, including costs of capital and depreciation per pig [€/pig/year].

$$
\pi_{m i l k}=\frac{1}{M}\left(p_{m i l k} * M-\sum p f_{i} * F_{i}\right)
$$

295 Where: $\pi_{\text {milk }}=$ partial gross margin per $\mathrm{kg}$ milk $[€ / \mathrm{kg}] ; \mathrm{M}=$ milk yield $[\mathrm{kg} / \mathrm{cow} /$ year $] ; p_{\text {milk }}=\operatorname{price}$ of milk $[€ / \mathrm{kg}]$; $296 \mathrm{pf}_{\mathrm{i}}=$ price of feed component $i[€ / \mathrm{kg}] ; \mathrm{F}_{\mathrm{i}}=$ intake of feed component $i[\mathrm{~kg} / \mathrm{cow} /$ year $]$

298 To derive average $\mathrm{N}$ abatement costs (AC), we calculated the differences in $\mathrm{N}$ losses and partial gross margins between the respective scenario and the reference case. Average abatement costs were then expressed as the difference in partial gross margin per $\mathrm{kg} \mathrm{N}$ abated, compared to REF (equation 4). In this step, all costs and subsidies related to production in general (rather than to the specific measures) would cancel out; we therefore considered a detailed assessment of these aspects unnecessary. Commonly used in relevant 304 literature for assessing individual abatement options (Bittman et al. 2014; Rößler et al. 2012; Van Vuuren et al. 2015), this measure of average on-farm abatement costs considers the 307 amount of emission reduction, rather than assuming that farmers gradually adjust their abatement efforts. In contrast, marginal abatement costs, which are the costs of abating one additional unit of emissions starting from a certain level, are used in national or sector economic analyses and to inform policymaking. For instance, marginal abatement cost 
311

curves can help to determine economically optimal levels of abatement, and are used for merit order ranking of different abatement measures (De Cara and Jayet 2011; Eory et al. 2013).

314 To account for interactions and co-benefits of simultaneously reducing $\mathrm{NH}_{3}, \mathrm{~N}_{2} \mathrm{O}$, and even 315 NO, the measure of abatement costs basically refers to the sum of these $\mathrm{N}$ species. However, for reasons of comparability with other studies, separate $\mathrm{AC}$ for $\mathrm{NH}_{3}, \mathrm{~N}_{2} \mathrm{O}$ and $\mathrm{NO}$ are indicated additionally. As the costs cannot reliably be attributed to different $\mathrm{N}$ species, these $\mathrm{AC}$ were derived by allocating all costs of the measures to each type of $\mathrm{N}$ emissions and thus contain considerable double counting of costs.

$$
A C_{i}=\frac{\pi_{i}-\pi_{R E F}}{N_{-} \operatorname{losS}_{i}-N_{-} \operatorname{losS}_{R E F}}
$$

320 Where: $A C_{i}=$ abatement cost for scenario $i[€ / k g N] ; \pi_{i}, R E F=$ partial gross margin in scenario $i$ and the reference 321 case, respectively $\left(\left[€ / \mathrm{kg}\right.\right.$ pork] and $\left[€ / \mathrm{kg}\right.$ milk], respectively); $N_{-}$loss $\mathrm{S}_{\mathrm{i}, \mathrm{REF}}=\mathrm{N}$ losses in scenario $\mathrm{i}$ and the 322 reference case, respectively ([kg N/kg pork] and [kg N/kg milk], respectively).

\subsection{Uncertainty analysis}

The parameters and assumptions first used to develop deterministic baselines (see section 2.4) are in reality linked with uncertainties, such as price fluctuations and variation in livestock performance and physiological characteristics (milk yield, $\mathrm{N}$ excretion). Furthermore, the uncertainty of $\mathrm{N}$ emission factors needs to be accounted for, as the exact amount of $\mathrm{N}$ emitted depends on a broad set of influencing factors and management practices.

To take these uncertainty aspects into consideration, we conducted a Monte Carlo uncertainty analysis. Monte Carlo analysis is a stochastic technique that uses random numbers and probability statistics to evaluate uncertain outcomes. More specifically, a 
randomly selected set of input values for uncertain parameters is fed into the simulation to derive related outputs. This procedure is repeated for numerous iterations (in our case $10000)$, and finally allows to estimate output uncertainty by mapping the results as new output-probability distribution functions (Benke et al. 2007; Bergsdal et al. 2007). By introducing statistical distributions for uncertain and variable input parameters, Monte Carlo analysis reduces the dependency on single point estimates and assumptions (Bergsdal et al. 2007; Evans et al. 2007). To define these probability distribution functions (pdf's) for the market prices of pork, milk, barley, wheat, soybean meal and rapeseed meal, monthly prices from 2000 to 2010 were adjusted by the price index of animal and plant-based agricultural products, respectively (LKÖ 2013). This correction removed the deterministic element of the variation in prices, i.e. inflation, and only considered stochastic variation (see also Finneran et al. (2012), who used a more complex approach). Most of the price distributions did not meet all criteria for normal distribution. We therefore modelled the prices with continuous 347 triangular distributions, based on the minimum, maximum and mode values of the index348 adjusted monthly prices. A continuous triangular probability distribution was also assumed 349 for the other stochastic variables (other feed components, investment cost, forage quality, 350 milk yield, $\mathrm{N}$ excretion and emission factors), where no larger data sets or longer time series 351 were available. Using triangular distributions to estimate probabilities under such data 352 constraints is common practice (Evans et al. 2007), and has also been used for estimating 353 emission factors (Lovett et al. 2008; Zehetmeier et al. 2014). The specific probability 354 distribution functions used in our analysis, and the corresponding data sources, are 355 summarised in Table A.3 in the Annex.

356 Correlations. Correlations need to be defined in order to avoid illogical and unrealistic 357 combinations of the randomly selected input values, which would distort the results. This 
serves to ensure that differences in model outputs between scenarios can be attributed to the examined $\mathrm{N}$ abatement measures, and not to randomly introduced biases through the simulation. For example, a cow with the physiological potential for a relatively high milk yield in the reference case must not be compared to a cow with a relatively low potential in the scenario. Due to large data sets available, specific mutual correlations could be determined between the prices of the feed inputs barley, soy, rape, wheat and plant oil, as well as pig and milk prices; all correlations with a significance level of 0.01 were used. For other variables, where testable data series were unavailable, correlations were purely based on logical connections. This applied to: $\mathrm{N}$ excretion rates for pig and dairy (correlation between reference case and scenarios), provision costs of grass and hay and attainable milk yield (reference case and scenario). All correlations used for the simulation can be found in Table A.4 in the Annex.

\section{Results}

The baseline calculations drew on literature data and yielded deterministic estimates of partial gross margins and $\mathrm{N}$ abatement. The uncertainty analysis, by contrast, generated estimates of the probability to arrive at a particular outcome, i.e. at a given profit margin or $\mathrm{N}$ loss. When presented as a cumulative distribution, probabilities can be specified for a 375 given outcome, e.g. how likely it is for a certain margin or $\mathrm{N}$ loss to be exceeded.

376 Partial gross margins (PGM). For both pig and dairy farming, the proposed $\mathrm{N}$ abatement 377 measures increased PGM compared to both reference scenarios. For pigs, optimised single378 phase and three-phase feeding surpassed the baseline of $1.19 € / \mathrm{kg}$ meat by 3.4 and 4.2 379 percent, at 1.23 and $1.24 € / \mathrm{kg}$, respectively. In milk production, improved forage quality 380 yielded a PGM of $0.28 € / \mathrm{kg}$, exceeding the baseline of $0.25 € / \mathrm{kg}$ milk by 12 percent. 
The cumulative probabilities of partial gross margins show that, even when allowing for considerable uncertainty in production costs and markets, the proposed abatement measures are economically preferable to the reference cases, and that farmers are highly likely to benefit from implementing them (Fig. 1). For the two pig feeding scenarios, PGM is almost identical; the probability is only 0.43 for S1_pig and 0.42 for S2_pig, respectively, that the gross margin is smaller than the baseline value of $1.19 € / \mathrm{kg}$ meat. In the REF case, this probability is 0.51 (in a slightly skewed pdf with a median below the mean value). The PGM for improving dairy forage quality (S_milk) has a probability of only 0.26 to be below the baseline value of $0.25 € / \mathrm{kg}$ milk; this is more likely to happen for the REF scenario, with a probability of 0.51 .

391 These results indicate that all considered measures make economic sense. Feeding 392 adjustments for pigs reduce the expensive protein components in the diet, which outweighs 393 the costs of investment and additional feed components such as synthetic amino acids and 394 plant oil. Higher milk yields of dairy cows compensate for increased feed provision costs 395 when enhancing forage quality.

$396 \mathbf{N}$ losses. Comparing the likely $\mathbf{N}$ losses of the reference cases with those of the scenarios 397 (Fig. 2) shows that the proposed feeding methods reduce $\mathrm{N}$ losses in most cases, and thus 398 effectively abate $\mathrm{N}$ emissions $\left(\mathrm{NH}_{3}, \mathrm{~N}_{2} \mathrm{O}\right.$ and $\left.\mathrm{NO}\right)$. Under all simulated production conditions, 399 phase feeding for pigs (S2_pigs) is likely to abate more $\mathrm{N}$ emissions than the optimised single 400 feed mix (S1_pig) (Fig. 2a). Higher-quality forage for dairy cows increases the total amount of $401 \quad \mathrm{~N}$ excretion and emissions per cow. These losses are however outweighed by an increase in 402 milk yields, thereby increasing overall nitrogen-efficiency (Fig. 2b).

$403 \quad$ [Insert Fig 1 here]

$404 \quad$ [Insert Fig 2 here] 
Abatement costs (AC) are negative under nearly all simulated production conditions (Table 3

and Fig. 3). For both pig scenarios, the probability of a negative AC is close to 1. In other words, the chance that an individual farmer is burdened with actual costs when implementing the measures is $0.1 \%$ in S2_pig, and even less in S1_pig. Both AC distributions have a similar degree of dispersion, and are between -52 and $+4 € / \mathrm{kg} \mathrm{N}$, for S1_pig and between -35 and $+5 € / \mathrm{kg} \mathrm{N}$ for S2_pig (Table 3). Thus, while S1_pig offers a slight economic advantage, S2_pig is more effective at reducing $\mathrm{N}$ losses (see above). Investment costs do not play a decisive role here. They range from $0.52 € /$ pig in the baseline calculation (based on initial investments of $€ 7500$ ) to a maximum of $2.09 € /$ pig (based on an investment of $30,000 €)$. The maximum investment would still only reduce the PGM from 1.24 to $1.22 € / \mathrm{kg}$ meat, considering a depreciation time of 15 years.

For milk production, the situation is even more evident as the Monte Carlo analysis shows no cases with abatement costs above 0 , and the AC probability distribution is less strongly dispersed than the respective distributions of the pig measures. Thus, it is very likely that the implementation of the measures is beneficial for each individual farmer. Abatement costs are of the same order of magnitude as for the pig measures (mean $-21 € / \mathrm{kg} \mathrm{N}$, Table 3 ). The economic feasibility of the dairy measure clearly depends on the increase in milk yield that is required to offset both the additional feeding costs and the additional $\mathrm{N}$ excretion per cow. With an average milk yield increase of $463 \mathrm{~kg} / \mathrm{cow} /$ year ( $\min 197, \max 866$, SD 113), the same gross margin per cow as in the reference can be maintained.

At first sight, S1_pig might seem preferable to S2_pig, due to its higher cost savings per kg N 426 abated. However, it is also important to consider absolute differences at farm level, as is 427 demonstrated by the baseline calculations: S1_pig generates roughly $5000 €$ of additional 428 gross margin and abates $250 \mathrm{~kg} \mathrm{~N}$, whereas S2_pig generates an additional $6600 €$ and 
abates $440 \mathrm{~kg} \mathrm{~N}$. A farmer aiming to maximise profits would opt for S2_pig, which offers

both more economic benefits and more $\mathrm{N}$ abatement.

As $\mathrm{NH}_{3}$ abatement accounts for the largest share (95\% of $\mathrm{N}$ abated), $\mathrm{NH}_{3}-\mathrm{N}$ abatement costs almost correspond to $\mathrm{AC}$ _total. Conversely, although $\mathrm{N}_{2} \mathrm{O}$ and $\mathrm{NO}$ abatement appears extremely beneficial for farmers in this way of presentation, it has to be considered that the total amount of avoided emissions is small.

[Insert Table 3 here]

[Insert Fig 3 here]

\section{Discussion}

Our results clearly demonstrate that measures to increase the $\mathrm{N}$ use efficiency of livestock production can simultaneously confer both economic and environmental benefit. Even without consideration of environmental benefits, the economic benefits presented here provide a reliable incentive for farmers to implement the measures. The link between these objectives, and the obvious incentive to minimise $\mathrm{N}$ losses, is the economic value of $\mathrm{N}$ in animal nutrition. At the farm level, this is reflected in negative average $\mathrm{N}$ abatement costs for the proposed $\mathrm{N}$-efficient feeding methods (mean values of $-21.2 € / \mathrm{kg} \mathrm{N}$ abated for S1_pig, -13.6 for S2_pig, -21.0 for S_milk); adopting these methods would reliably increase farmers' margins, even in the face of considerable uncertainties in production costs and product markets. Although the existence of negative abatement costs (i.e., "win-win" 448 situations) for certain measures is well known, adoption rates are not always as high as 449 would be expected (Glenk et al. 2014; MacLeod et al. 2010). We discuss this in more detail 450 below.

451 Our estimates of economic gains are higher than those by Bittman et al. (2014) who 452 estimated $\mathrm{NH}_{3}$ abatement costs of low-protein feeding strategies between -2 and $+2 €$ per kg 
$453 \mathrm{NH}_{3}-\mathrm{N}$ saved. However, due to large differences in costs and emissions, both between

European countries and between animal categories, that estimate remains fairly rough especially as the authors did not define a specific reference situation. Rößler et al. (2012) calculated abatement costs for pig feeding measures in Germany in a range of -11.4 to $16.5 €$ per $\mathrm{kg} \mathrm{NH}_{3}-\mathrm{N}$ saved, depending on the reference case and size of the farm, which is close to the results presented here (values have been converted from $€ / \mathrm{kg} \mathrm{NH}_{3}$ to $€ / \mathrm{kg} \mathrm{NH} \mathrm{N}^{-}$ $\mathrm{N}$ by multiplying by a factor of $17 / 14)$. Van Vuuren et al. (2015) estimated changes in pig production costs between -2.4 and $+7.3 €$ per $\mathrm{kg} \mathrm{NH}_{3}-\mathrm{N}$ reduced, and costs of up to $+75.3 €$ per $\mathrm{kg} \mathrm{NH} \mathrm{NH}_{3} \mathrm{~N}$ when not supplementing synthetic amino acids. The authors found that, similar to pigs, low- $\mathrm{N}$ feeding strategies for dairy cows may induce net benefits or costs (abatement costs of -1.70 to $+7.3 €$ per $\mathrm{kg} \mathrm{NH}_{3}-\mathrm{N}$ ) (van Vuuren et al. 2015). However, in contrast to the present study, those studies only accounted for ammonia abatement. While $\mathrm{NH}_{3}$ contributes the largest share of gaseous agricultural $\mathrm{N}$ emissions, $\mathrm{N}_{2} \mathrm{O}$ and $\mathrm{NO}$ emissions from manure management and soils should also be considered for a more complete analysis. The data from such assessments can then also be used to identify trade-offs and synergies between mitigating $\mathrm{N}$ pollution and climate change. For instance, increasing milk yields has not only been recognised as an effective measure to abate $\mathrm{N}$ but also to reduce methane emissions from dairy production (Yan et al. 2010).

Sensitivities. In modelling $\mathrm{N}$ abatement costs, algorithms govern the effect of a given 472 uncertainty in the input parameters on the uncertainty of the corresponding outputs. When 473 interpreting simulation results, the following characteristics determine the influence of an 474 input term to the overall outputs: (i) for multiplicative terms, input uncertainty is directly 475 transferred to the output, such that factors with larger uncertainty contribute to overall 476 uncertainty directly depending on their relative magnitude (i.e., in \%). With most input 
477 factors having been assigned similar uncertainty factors (see Table A.3) these influences are

478 similar for most parameters. In the algorithms used in this study, terms are mostly linked up 479 by multiplication. (ii) Abatement cost calculation compares results of a given scenario with 480 that of the reference case. Both elements are derived using a very similar approach and 481 identical inputs, so that a differentiation of contributing factors is not possible. (iii) As 482 investment costs per pig are small, their uncertainty does not markedly affect the results. 483 Similarly, the uncertainties of meat/milk prices are much smaller than those of prices for 484 feed ingredients and mixtures, and thus of lower importance for the uncertainty of results. 485 In consequence, the uncertainties in feed prices and $\mathrm{N}$ excretion (implemented as 486 multiplicative terms) have the greatest effect on the overall output uncertainties. Due to the 487 importance of correlation between the individual input parameters, it is not possible to

further differentiate these parameters and their specific impact on the overall results.

Economic rationale and decision-making. A set of assumptions has been used to construct specific measures and simulate the financial and environmental effects of their implementation. The assumption here was that farmers will make a "yes or no"-decision based on whether the proposed measure is economically beneficial for their operation. Other approaches (such as linear programming or nonlinear optimisation) mostly come from economics and aim to maximise profitability or return of capital by optimising production parameters under given constraints and market conditions (Morel et al. 2012; Niemi et al. 2010). Economic risks related to market price fluctuations and uncertainties might help explain why (risk-averse) farmers hesitate to implement measures which follow this rationale (Finneran et al. 2012). It is therefore important to look beyond purely economic factors and realise that farmers act in a complex socio-ecological system: Although they need to maintain their farms' profitability and thus adopt an economic rationale to some 
extent, farms are more than just businesses; their production possibilities, and their actual

production and income are highly dependent on natural resources, geographic location, weather and climate, and they face many risks and variabilities. Furthermore, besides food production, agriculture fulfils multiple functions and responsibilities, such as the maintenance of cultural landscape, biodiversity and ecosystem functions (Rossing et al. 2007). In this sense, Feola and Binder (2010) emphasise the need to consider the complex, multi-scale and multi-level nature of agricultural systems when formulating pertinent concepts and integrative models. Achieving economic objectives is most likely not the farmers' only motivation and cause for action, as is shown by sometimes low adoption rates despite negative abatement costs for certain measures (Glenk et al. 2014). This points to the existence of non-financial barriers and motivating factors that drive farmers' behaviour, such as age, education and experience of the farmers as well as social aspects including attitudes 513 and perceptions, social norms and context, imitation of others, or role models (Barnes and 514 Toma 2011; Feola and Binder 2010; Glenk et al. 2014). Furthermore, consumer demand or 515 farm specific constraints such as the suitability and availability of surrounding land, labour 516 constraints or access to technology can play a role (Glenk et al. 2014). A growing body of 517 literature examines such behavioural aspects of decision-making processes, in several cases 518 applying agent-based modelling (Feola and Binder 2010; Reise et al. 2012; Skevas et al. 519 2012). Nevertheless, economic viability and profitability of $\mathrm{N}$ abatement measures, as 520 assessed in the present study, appear as important starting points. They are necessary for 521 developing sustainable emission reduction strategies, but probably insufficient as sole 522 incentive for farmers to take action and adopt new (feeding) practices. Further research into 523 farmers' decision-making and perception of $\mathrm{N}$ reduction measures will thus be indispensable 524 to enhance implementation. 
Integrating economic and environmental aspects, we assessed the potential of three different animal feeding measures to make livestock farming more $\mathrm{N}$-efficient - two measures for fattening pigs, and one for dairy cattle. Results show that those measures are economically beneficial for farmers and at the same time effectively reduce $\mathrm{N}$ losses to the environment. Optimised single-phase feeding and three-phase feeding for pigs reduce expensive protein components in the diet, which outweighs the costs connected with the two measures. Improving the quality of dairy forage distinctly increases milk yields and thereby compensates for increased $\mathrm{N}$ excretion and forage provision costs. The dairy measure and the optimised single-phase feeding for pigs can be adopted by farmers without needing to commit to long-term investment costs. As $\mathrm{N}$ loss is lower and partial gross margins higher for all cases for the three-phase feeding for pigs, extension services and policy should advise those farmers who know that their farming operation will be continued to invest in this technology. This is particularly relevant when the farmer is already planning to add or modify pig housing, as feeding equipment could be installed more cheaply in conjunction with other construction measures.

A Monte Carlo uncertainty analysis revealed that the generally positive conclusion not only holds for a point-estimate based on specific assumptions, but is also robust to possible market fluctuations, different physiological conditions of the livestock and variability in emission factors. Thus, the results are not limited to one specific single case based on static assumptions. The simulation results further confirm the effectiveness and wide applicability of the proposed $\mathrm{N}$ abatement measures, despite production conditions placing some restrictions on the choices available. By investigating measures related to both pig and dairy production in one study, we illustrated that $\mathrm{N}$ abatement costs (or, in this case, abatement 
benefits) can be comparable between husbandry systems. This also clearly shows that there

is scope for simultaneous action in several fields. The approach used in this study can be applied to a range of situations, where the feasibility and effectiveness of implementing proposed measures in agriculture needs to be assessed, and communicated. Enhancing the adoption of these measures, however, will require more insights into farmers' decisionmaking behaviour and potential non-financial barriers to implementation as a prerequisite to develop specific policies. In the further debate on this topic, closer attention should be paid to specific background conditions under which farmers operate, such as the EU Common Agricultural Policy (CAP) and related grants and subsidies. Those policy instruments can provide further leverage for the introduction of agricultural measures and help bridge the science-policy gap, even in cases where measures are not per se profitable under current market conditions, but desired and valued politically. Ultimately, evidence-based guidance for individual farms needs to be part of a broader strategy to minimise external costs and to maximise environmental benefits for society as a whole.

\section{Annex}

[Insert Table A.1 here]

[Insert Table A.2 here]

[Insert Table A.3 here]

[Insert Table A.4 here]

\section{References}

571 Aarnink A, Verstegen M (2007) Nutrition, key factor to reduce environmental load from pig 572 production. Livestock Science 109(1-3):194-203. doi: 10.1016/j.livsci.2007.01.112 
ALB Hessen (2008) Richtpreise für den Neu- und Umbau landwirtschaftlicher Wirtschaftsgebäude und ländlicher Wohnhäuser: Ausgabe 2009/2010

Amon B, Winiwarter W, Anderl M, Baumgarten A, Dersch G, Guggenberger T, Hasenauer H, Kantelhardt J, Kasper M, Kitzler B, Moser T, Pötzelsberger E, Prosenbauer M, Schaller L, Schröck A, Sigmund E, Zechtmeister-Boltenstern E, Zethner G (2014) Farming for a Better Climate (FarmClim). Design of an Inter- and Transdisciplinary Research Project Aiming to Address the "Science-Policy Gap". gaia 23(2):118-124. doi: 10.14512/gaia.23.2.9

AWI (2015) IDB Deckungsbeiträge und Kalkulationsdaten, Vienna

Barnes AP, Toma L (2012) A typology of dairy farmer perceptions towards climate change. Climatic Change 112(2):507-522. doi: 10.1007/s10584-011-0226-2

Benke KK, Hamilton AJ, Lowell KE (2007) Uncertainty analysis and risk assessment in the management of environmental resources. Australasian Journal of Environmental Management 14(4):243-249. doi: 10.1080/14486563.2007.10648722

Bergsdal H, Bohne RA, Bratteb $\varnothing \mathrm{H}$ (2007) Projection of Construction and Demolition Waste in Norway. Journal of Industrial Ecology 11(3):27-39. doi: 10.1162/jiec.2007.1149

Bittman S, Dedina M, Howard C, Oenema O, Sutton MA (2014) Options for Ammonia Mitigation. Guidance from the UNECE Task Force on Reactive Nitrogen, Edinburgh, UK

Dalgaard T, Hansen B, Hasler B, Hertel O, Hutchings NJ, Jacobsen BH, Stoumann Jensen L, Kronvang B, Olesen JE, Schjørring JK, Sillebak Kristensen I, Graversgaard M, Termansen M, Vejre H (2014) Policies for agricultural nitrogen management-trends, challenges and prospects for improved efficiency in Denmark. Environ. Res. Lett. 9(11):115002. doi: 10.1088/1748-9326/9/11/115002

Dämmgen U, Brade W, Schulz J, Kleine Klausing H, Hutchings NJ, Haenel H, Rösemann C (2011) The effect of feed composition and feeding strategies on excretion rates in German pig production. Landbauforschung vTI Agriculture and Forestry Research 61(4):327-342

De Cara S, Jayet P.-A (2011) Marginal abatement costs of greenhouse gas emissions from European agriculture, cost effectiveness, and the EU non-ETS burden sharing agreement. Ecological Economics 70(9):1680-1690. doi: 10.1016/j.ecolecon.2011.05.007

DLG (2015) Fachinfos Futtermittel Rinder. http://www.dlg.org/fachinfos-rinder.html. Accessed 15 May 2015

Döhler H, Eurich-Menden B, Rößler R, Vandré R, Wulf S (2011) Systematic Cost-Benefit Analysis of Mitigation Measures for Agricultural Ammonia Emissions, Supporting National Costing Analysis, Dessau-Roßlau

Dourmad J, Jondreville C (2007) Impact of nutrition on nitrogen, phosphorus, $\mathrm{Cu}$ and $\mathrm{Zn}$ in pig manure, and on emissions of ammonia and odours. Livestock Science 112(3):192-198. doi: 10.1016/j.livsci.2007.09.002

Eory V, Topp CF, Moran D (2013) Multiple-pollutant cost-effectiveness of greenhouse gas mitigation measures in the UK agriculture. Environmental Science \& Policy 27:55-67. doi: 10.1016/j.envsci.2012.11.003

Erisman JW, Galloway JN, Seitzinger S, Bleeker A, Dise NB, Petrescu R, Leach AM, Vries W de (2013) Consequences of human modification of the global nitrogen cycle. Philosophical Transactions of the Royal Society B: Biological Sciences(368: 20130116.)

Ertl P, Knaus W, Steinwidder A (2014) Comparison of zero concentrate supplementation with different quantities of concentrates in terms of production, animal health, and profitability of organic dairy farms in Austria. Org. Agr. 4(3):233-242. doi: 10.1007/s13165-014-0077-z

European Environment Agency (EEA) (2013) EMEP/EEA air pollutant emission inventory guidebook 2013. Technical guidance to prepare national emission inventories, Luxembourg 
Eurostat (2014) Pig farming sector - statistical portrait 2014: Statistics Explained

Evans JR, Sperow M, D'Souza GE, Rayburn EB (2007) Stochastic Simulation of Pasture-Raised Beef Production Systems and Implications for the Appalachian Cow-Calf Sector. Journal of Sustainable Agriculture 30(4):27-51. doi: 10.1300/J064v30n04_04

Feola G, Binder CR (2010) Towards an improved understanding of farmers' behaviour: The integrative agent-centred (IAC) framework. Ecological Economics 69(12):2323-2333. doi: 10.1016/j.ecolecon.2010.07.023

Finneran E, Crosson P, O'Kiely P, Shalloo L, Forristal D, Wallace M (2012) Stochastic simulation of the cost of home-produced feeds for ruminant livestock systems. J. Agric. Sci. 150(01):123-139. doi: $10.1017 /$ S002185961100061X

Fowler D, Coyle M, Skiba U, Sutton MA, Cape JN, Reis S, Sheppard LJ, Jenkins A, Grizzetti B, Galloway JN, Vitousek P, Leach A, Bouwman AF, Butterbach-Bahl K, Dentener F, Stevenson D, Amann M, Voss M (2013) The global nitrogen cycle in the twenty-first century. Philosophical Transactions of the Royal Society B: Biological Sciences 368(1621):20130164. doi: 10.1098/rstb.2013.0164

Galloway JN, Dentener FJ, Capone DG, Boyer EW, Howarth RW, Seitzinger SP, Asner GP, Cleveland CC, Green PA, Holland EA, Karl DM, Michaels AF, Porter JH, Townsend AR, Vörösmarty CJ (2004) Nitrogen Cycles: Past, Present, and Future. Biogeochemistry 70(2):153-226. doi: 10.1007/s10533004-0370-0

Galloway JN, Townsend AR, Erisman JW, Bekunda M, Cai Z, Freney JR, Martinelli LA, Seitzinger SP, Sutton MA (2008) Transformation of the Nitrogen Cycle: Recent Trends, Questions, and Potential Solutions. Science 320(5878):889-892. doi: 10.1126/science.1136674

Glenk K, Eory V, Colombo S, Barnes A (2014) Adoption of greenhouse gas mitigation in agriculture: An analysis of dairy farmers' perceptions and adoption behaviour. Ecological Economics 108:49-58. doi: 10.1016/j.ecolecon.2014.09.027

Gruber L, Pötsch EM (2006) Calculation of nitrogen excretion of dairy cows in Austria. Die Bodenkultur 57(2):65-72

Gruber L, Steinwidder A, Stefanon B, Steiner B, Steinwender R (1999) Influence of grassland management in Alpine regions and concentrate level on $\mathrm{N}$ excretion and milk yield of dairy cows. Livestock Production Science 61(2-3):155-170. doi: 10.1016/S0301-6226(99)00065-2

Hörtenhuber S, Lindenthal T, Amon B, Markut T, Kirner L, Zollitsch W (2010) Greenhouse gas emissions from selected Austrian dairy production systems-model calculations considering the effects of land use change. Renewable Agriculture and Food Systems 25(04):316-329

Hörtenhuber SJ, Lindenthal T, Zollitsch W (2011) Reduction of greenhouse gas emissions from feed supply chains by utilizing regionally produced protein sources: the case of Austrian dairy production. J. Sci. Food Agric. 91(6):1118-1127. doi: 10.1002/jsfa.4293

IPCC (2006a) IPCC Guidelines for National Greenhouse Gas Inventories: Volume 4, Chapter 10 Emissions from Livestock and Manure Management

IPCC (2006b) IPCC Guidelines for National Greenhouse Gas Inventories: Volume 1, Chapter 3 Uncertainties

Jongebreur AA, Monteny GJ, Ogink N (2005) Livestock production and emissions of volatile gases. In: Kuczynski T, Dämmgen U, Webb J, Myczko A (eds) Emissions from European agriculture. Wageningen Academic Publishers, Wageningen, pp. 19-34

Klimont Z, Brink C (2004) Modelling of Emissions of Air Pollutants and Greenhouse Gases from Agricultural Sources in Europe: Interim Report IR-04-048, Laxenburg

Kornegay ET, Harper AF (1997) Environmental nutrition: nutrient management strategies to reduce nutrient excretion of swine. The Professional Animal Scientist 13(3):99-111 
Landesbetrieb Landwirtschaft Hessen (2012) Futterberehnungsprogramm für Schweine in Anlehnung an die GfE- und DLG-Versorgungsempfehlungen von 2006, 2008 und 2010

LKÖ (2013) Agrarindex Monatswerte. Austrian Chamber of Agriculture. https://www.lko.at/media.php?filename=download\%3D\%2F2014.12.29\%2F1419858751982163. pdf\&rn=Agrarindex\%201995\%3D100\%20\%28Monatswerte\%29.pdf. Accesssed 06 March 2015

Lovett DK, Shalloo L, Dillon P, O'Mara FP (2008) Greenhouse gas emissions from pastoral based dairying systems: The effect of uncertainty and management change under two contrasting production systems. Livestock Science 116(1-3):260-274. doi: 10.1016/j.livsci.2007.10.016

MacLeod M, Moran D, Eory V, Rees RM, Barnes A, Topp CF, Ball B, Hoad S, Wall E, McVittie A, Pajot G, Matthews R, Smith P, Moxey A (2010) Developing greenhouse gas marginal abatement cost curves for agricultural emissions from crops and soils in the UK. Agricultural Systems 103(4):198209. doi: $10.1016 /$ j.agsy.2010.01.002

Marston SP, Clark GW, Anderson GW, Kersbergen RJ, Lunak M, Marcinkowski DP, Murphy MR, Schwab CG, Erickson PS (2011) Maximizing profit on New England organic dairy farms: an economic comparison of 4 total mixed rations for organic Holsteins and Jerseys. J. Dairy Sci. 94(6):3184-3201. doi: 10.3168/jds.2010-3778

Morel P, Sirisatien D, Wood GR (2012) Effect of pig type, costs and prices, and dietary restraints on dietary nutrient specification for maximum profitability in grower-finisher pig herds: A theoretical approach. Livestock Science 148(3):255-267. doi: 10.1016/j.livsci.2012.06.015

Moser T, Kantelhardt J, Schaller L, Amon B, Zechmeister-Boltenstern S, Kaspar M, Hasenauer H, Pötzelsberger E, Kitzler B, Winiwarter W, Schröck A, Zethner G, Anderl M, Baumgarten A, Dersch G, Prosenbauer M (2013) Economic Assessment in the ACRP-Project FarmCLIM. In: Proceedings of the ÖGA 2013 (23.ÖGA-Jahrestagung), pp. 141-142

Nahm KH (2002) Efficient Feed Nutrient Utilization to Reduce Pollutants in Poultry and Swine Manure. Critical Revs. in Env. Sc. \& Tech. 32(1):1-16. doi: 10.1080/10643380290813435

Newell Price JP, Harris D, Taylor M, Williams JR, Anthony SG, Duethmann D, Gooday RD, Lord El, Chambers BJ, Chadwick DR, Misselbrook TH (2011) An Inventory of Mitigation Methods and Guide to their Effects on Diffuse Water Pollution, Greenhouse Gas Emissions and Ammonia Emissions from Agriculture: User Guide. Part of Defra Project WQ0106

Niemi JK, Sevón-Aimonen M, Pietola K, Stalder KJ (2010) The value of precision feeding technologies for grow-finish swine. Livestock Science 129(1-3):13-23. doi: 10.1016/j.livsci.2009.12.006

Pomar C, Pomar J, Dubeau F, Joannopoulos E, Dussault J (2014) The impact of daily multiphase feeding on animal performance, body composition, nitrogen and phosphorus excretions, and feed costs in growing-finishing pigs. Animal an international journal of animal bioscience 8(5):704-713. doi: 10.1017/S1751731114000408

Pötsch EM (2006) Österreichisches Aktionsprogramm zur Umsetzung der EU-Nitratrichtlinie: Aktualisierung der N-Ausscheidungsrate für landwirtschaftliche Nutztiere - Konsequenzen für die Praxis

Powell JM (2014) Feed and manure use in low- $\mathrm{N}$-input and high-N-input dairy cattle production systems. Environ. Res. Lett. 9(11):115004. doi: 10.1088/1748-9326/9/11/115004

Powell JM, MacLeod M, Vellinga TV, Opio C, Falcucci A, Tempio G, Steinfeld H, Gerber P (2013) Feedmilk-manure nitrogen relationships in global dairy production systems. Livestock Science 152(23):261-272. doi: 10.1016/j.livsci.2013.01.001

Reis S, Sutton MA, Howard C (eds) (2015) Costs of Ammonia Abatement and the Climate Co-Benefits. Springer, Dordrecht 
Reise C, Musshoff O, Granoszewski K, Spiller A (2012) Which factors influence the expansion of bioenergy? An empirical study of the investment behaviours of German farmers. Ecological Economics 73:133-141. doi: 10.1016/j.ecolecon.2011.10.008

Rejesus RM, Hornbaker RH (1999) Economic and environmental evaluation of alternative pollutionreducing nitrogen management practices in central Illinois. Agriculture, Ecosystems \& Environment 75(1-2):41-53. doi: 10.1016/S0167-8809(99)00058-4

Resch R (2007) Neue Futterwerttabellen für den Alpenraum

Rossing W, Zander P, Josien E, Groot J, Meyer BC, Knierim A (2007) Integrative modelling approaches for analysis of impact of multifunctional agriculture: A review for France, Germany and The Netherlands. Agriculture, Ecosystems \& Environment 120(1):41-57. doi: 10.1016/j.agee.2006.05.031

Rößler R, Eurich-Menden B, Vandré R, Wulf S, Döhler H (2012) Ammonia emissions: Abatement costs for feeding of fattening pigs. Landtechnik 67(1):69-72

Roth FX, Schwarz FJ, Stangl GI (eds) (2011) Kirchgeßner Tierernährung: Leitfaden für Studium, Beratung und Praxis. DLG-Verlag, Frankfurt am Main

Rotz C (2004) Management to reduce nitrogen losses in animal production. Journal of Animal Science 82:E119-E137

Ryan M (2005) Calculating abatement costs. In: Kuczynski T, Dämmgen U, Webb J, Myczko A (eds) Emissions from European agriculture. Wageningen Academic Publishers, Wageningen, pp. 253262

Ryan W, Hennessy D, Murphy JJ, Boland TM, Shalloo L (2011) A model of nitrogen efficiency in contrasting grass-based dairy systems. J. Dairy Sci. 94(2):1032-1044. doi: 10.3168/jds.2010-3294

Skevas T, Stefanou SE, Lansink AO (2012) Can economic incentives encourage actual reductions in pesticide use and environmental spillovers? Agricultural Economics 43(3):267-276. doi: 10.1111/j.1574-0862.2012.00581.x

Spiekers H, Eurich-Menden B, Van den Weghe, Herman (2015) Anders füttern, Ammoniak runter. DLG-Mitteilungen(10):86-88

Statistics Austria (2014) Land- und forstwirtschaftliche Erzeugerpreise für Österreich ab 1998, Vienna

Steinwidder A, Guggenberger T (2003) Investigations on feed intake and nutrient supply of dairy cows as well as nutrient balance studies on farms in grassland regions of Austria. (in German). Die Bodenkultur 54(1):49-66

Umweltbundesamt (2014a) Austria's Informative Inventory Report (IIR) 2014: Submission under the UNECE Convention on Long-range Transboundary Air Pollution

Umweltbundesamt (2014b) Austria's National Inventory Report 2014: Submission under the United Nations Framework Convention on Climate Change and the Kyoto Protocol

UNFCCC (2014) National Inventory Submissions 2014 - Common Reporting Format (CRF). http://unfccc.int/national_reports/annex_i_ghg_inventories/national_inventories_submissions/it ems/8108.php. Accessed 30 June 2015

van Vuuren AM, Pineiro C, van der Hoek K, Oenema O (2015) Economics of Low Nitrogen Feeding Strategies. In: Reis S, Sutton MA, Howard C (eds) Costs of Ammonia Abatement and the Climate Co-Benefits. Springer, Dordrecht

Vibart RE, Washburn SP, Green JT, Benson GA, Williams CM, Pacheco D, Lopez-Villalobos N (2012) Effects of feeding strategy on milk production, reproduction, pasture utilization, and economics of autumn-calving dairy cows in eastern North Carolina. J. Dairy Sci. 95(2):997-1010. doi: 10.3168/jds.2011-4755 
Winiwarter W, Rypdal K (2001) Assessing the uncertainty associated with national greenhouse gas emission inventories: a case study for Austria. Atmospheric Environment 35:5425-5440

Yan T, Mayne CS, Gordon FG, Porter MG, Agnew RE, Patterson DC, Ferris CP, Kilpatrick DJ (2010) Mitigation of enteric methane emissions through improving efficiency of energy utilization and productivity in lactating dairy cows. J. Dairy Sci. 93(6):2630-2638. doi: 10.3168/jds.2009-2929

Zehetmeier M, Gandorfer M, Hoffmann H, Müller UK, Boer I de, Heißenhuber A (2014) The impact of uncertainties on predicted greenhouse gas emissions of dairy cow production systems. Journal of Cleaner Production 73:116-124. doi: 10.1016/j.jclepro.2013.09.054 
Tables

1

Table 1: Pig phase feeding - Scenario assumptions

\begin{tabular}{|c|c|c|c|}
\hline Pigs: phase feeding & $\begin{array}{l}\text { Reference } \\
\text { scenario (REF_pig) }\end{array}$ & $\begin{array}{l}\text { Scenario } 1 \\
\text { (S1_pig) }\end{array}$ & $\begin{array}{l}\text { Scenario } 2 \\
\text { (S2_pig) }\end{array}$ \\
\hline & $\begin{array}{l}\text { Single-phase } \\
\text { feeding }\end{array}$ & $\begin{array}{l}\text { Optimised single- } \\
\text { phase feeding }\end{array}$ & 3-phase feeding \\
\hline \multicolumn{4}{|l|}{ Feed components [kg/fattening pig] } \\
\hline Barley & 63.5 & 127 & 127 \\
\hline Soybean meal 44\% XP & 50.8 & 40.64 & 31.07 \\
\hline Wheat & 132.08 & 78.232 & 88.84 \\
\hline Minerals & 7.62 & 5.08 & 4.74 \\
\hline Plant oil & 0 & 2.54 & 1.83 \\
\hline L-Lysine $H C L$ & 0 & 0.508 & 0.508 \\
\hline Total [kg/fattening pig] & 254 & 254 & 254 \\
\hline Average crude protein content [\%] & $19.0 \%$ & $17.7 \%$ & $16.6 \%$ \\
\hline $\begin{array}{l}\text { Additional investment [€] } \\
\text { (depreciated over } 15 \text { years) }\end{array}$ & - & - & 7500 \\
\hline Slaughter weight [kg/fattening pig] & \multicolumn{3}{|c|}{96} \\
\hline Fattening places per farm & \multicolumn{3}{|c|}{450} \\
\hline Turnover rate & \multicolumn{3}{|c|}{2.67} \\
\hline $\mathrm{N}$ excretion [kg N/fattening pig] & 3.86 & \begin{tabular}{|r|}
3.29 \\
\end{tabular} & 2.85 \\
\hline Sources & \multicolumn{3}{|c|}{$\begin{array}{l}\text { Feed components: AWI } 2015 \text { (REF); Roth et al. } 2011 \text { (S1, S2) } \\
\text { Protein contents: Dämmgen et al. } 2011 \\
\text { Other production traits: AWI } 2015 \\
\text { N excretion: Umweltbundesamt } 2014 \text { b (REF), calc. (S1, S2) }\end{array}$} \\
\hline
\end{tabular}


Table 2: Dairy cattle forage quality - Scenario assumptions

\begin{tabular}{|c|c|c|c|c|}
\hline Dairy: forage quality & \multicolumn{2}{|c|}{ Reference scenario (REF_milk) } & \multicolumn{2}{|c|}{ Scenario (S_milk) } \\
\hline Forage quality & \multicolumn{2}{|c|}{ Medium } & \multicolumn{2}{|c|}{ High } \\
\hline Forage & $\begin{array}{l}\text { Intake } \\
\text { [dt } \\
\text { DM/cow/year] }\end{array}$ & $\begin{array}{l}\text { Quality } \\
\text { [MJ NEL/kg DM] }\end{array}$ & $\begin{array}{l}\text { Intake } \\
\text { [dt } \\
\text { DM/cow/year] }\end{array}$ & $\begin{array}{l}\text { Quality } \\
\text { [MJ NEL/kg DM] }\end{array}$ \\
\hline Grass-silage & 26.1 & 5.9 & 35.6 & 6.3 \\
\hline Maize-silage & 8.0 & 6.7 & 11.0 & 6.7 \\
\hline Hay & 6.0 & 5.2 & 8.2 & 5.5 \\
\hline Concentrate feed & $\begin{array}{l}\text { intake } \\
{[\mathrm{kg}} \\
\mathrm{DM} / \text { cow/year] }\end{array}$ & $\begin{array}{l}\text { quality } \\
\text { [MJ NEL/kg DM] }\end{array}$ & $\begin{array}{l}\text { intake } \\
{[\mathrm{kg}} \\
\mathrm{DM} / \text { cow/year }]\end{array}$ & $\begin{array}{l}\text { quality } \\
\text { [MJ NEL/kg DM] }\end{array}$ \\
\hline Barley & 452.6 & 8.07 & 452.6 & 8.07 \\
\hline Soybean meal & 302.95 & 8.60 & 302.95 & 8.60 \\
\hline Rapeseed meal & 302.95 & 7.20 & 302.95 & 7.20 \\
\hline Dairy compound feed & 452.6 & 8.05 & 452.6 & 8.05 \\
\hline $\begin{array}{l}\text { Total energy intake } \\
\text { [MJ NEL/cow/year] }\end{array}$ & \multicolumn{2}{|c|}{35991} & \multicolumn{2}{|c|}{46355} \\
\hline $\begin{array}{l}\text { Milk yield total } \\
{[\mathrm{kg} / \text { cow } / \text { year }]}\end{array}$ & \multicolumn{2}{|c|}{6491} & \multicolumn{2}{|c|}{9632} \\
\hline $\begin{array}{l}\text { Milk for calves } \\
{[\mathrm{kg} / \text { cow/year }]}\end{array}$ & \multicolumn{2}{|c|}{300} & \multicolumn{2}{|c|}{300} \\
\hline $\begin{array}{l}\text { Milk yield available for sale } \\
\text { [kg/cow/year] }\end{array}$ & \multicolumn{2}{|c|}{6191} & \multicolumn{2}{|c|}{9332} \\
\hline $\begin{array}{l}\mathrm{N} \text { excretion } \\
{[\mathrm{kg} \mathrm{N} / \text { animal*year] }}\end{array}$ & \multicolumn{2}{|c|}{98.82} & \multicolumn{2}{|c|}{119.74} \\
\hline Sources & \multicolumn{4}{|c|}{$\begin{array}{l}\text { Feed intake: FarmClim (Moser et al 2013), AWI } 2015 \\
\text { Feed quality: AWI 2015; Hörtenhuber et al. 2010; DLG 2015, Resch } \\
2007 \\
\text { Milk yield: calculated based on AWI } 2015 \\
\text { N excretion: calc. based on Gruber et al. } 1999\end{array}$} \\
\hline
\end{tabular}


Table 3: Abatement costs of the analysed measures.

\begin{tabular}{|c|c|c|c|}
\hline & \multicolumn{2}{|l|}{ Pig } & \multirow{2}{*}{$\begin{array}{l}\text { Milk } \\
\text { S }\end{array}$} \\
\hline & S1 & S2 & \\
\hline \multicolumn{4}{|l|}{ Total abatement cost (AC_total) } \\
\hline Baseline value [€/kg $\mathrm{N}$ abated] & -20.05 & -15.08 & -18.17 \\
\hline \multicolumn{4}{|l|}{ Stochastic simulation [€/kg N abated] } \\
\hline Mean & -21.16 & -13.56 & -21.01 \\
\hline Minimum & -51.64 & -35.01 & -40.17 \\
\hline Maximum & 4.30 & 4.91 & -11.45 \\
\hline Standard deviation (SD) & 6.72 & 4.90 & 3.56 \\
\hline \multicolumn{4}{|l|}{$\mathrm{NH}_{3}-\mathrm{N}$ abatement cost $\left(\mathrm{AC} \_\mathrm{NH}_{3}\right)$} \\
\hline Baseline value [ $€ / \mathrm{kg} \mathrm{NH}_{3}-\mathrm{N}$ abated] & -21.13 & -15.89 & -19.09 \\
\hline \multicolumn{4}{|l|}{ 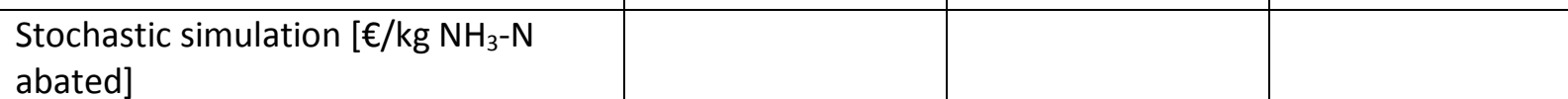 } \\
\hline Mean & -22.58 & -14.47 & -22.26 \\
\hline Minimum & -55.23 & -37.39 & -43.63 \\
\hline Maximum & 4.55 & 5.32 & -12.13 \\
\hline Standard deviation (SD) & 7.21 & 5.26 & 3.85 \\
\hline \multicolumn{4}{|l|}{$\mathrm{N}_{2} \mathrm{O}-\mathrm{N}$ abatement cost $\left(\mathrm{AC} \_\mathrm{N}_{2} \mathrm{O}\right)$} \\
\hline Baseline value [ $€ / \mathrm{kg} \mathrm{N}_{2} \mathrm{O}-\mathrm{N}$ abated] & -673.15 & -506.24 & -661.83 \\
\hline \multicolumn{4}{|l|}{$\begin{array}{l}\text { Stochastic simulation [ } € / \mathrm{kg} \mathrm{N}_{2} \mathrm{O}-\mathrm{N} \\
\text { abated]] }\end{array}$} \\
\hline Mean & -597.96 & -383.05 & -701.21 \\
\hline Minimum & -1863.33 & -1360.43 & -1863.29 \\
\hline Maximum & 144.42 & 126.68 & -279.64 \\
\hline Standard deviation (SD) & 235.18 & 165.47 & 206.56 \\
\hline \multicolumn{4}{|l|}{ NO-N abatement cost (AC_NO) } \\
\hline Baseline value [€/kg NO-N abated] & -927.44 & -697.47 & -895.16 \\
\hline \multicolumn{4}{|l|}{$\begin{array}{l}\text { Stochastic simulation [€/kg NO-N } \\
\text { abated] }\end{array}$} \\
\hline Mean & -910.07 & -582.99 & -958.79 \\
\hline Minimum & -3081.34 & -2167.51 & -2619.88 \\
\hline Maximum & 166.44 & 131.81 & -379.83 \\
\hline Standard deviation (SD) & 388.62 & 269.97 & 301.94 \\
\hline
\end{tabular}


Table A.1: N excretion fattening pigs in the EU28 (Source: UNFCCC 2014, Eurostat 2014)

\begin{tabular}{|l|l|l|}
\hline & $\begin{array}{l}\text { N excretion } \\
\text { [kg N/pig/year] }\end{array}$ & $\begin{array}{l}\text { Slaughter weight } \\
\text { [kg/pig] }\end{array}$ \\
\hline Ireland & 6.68 & 97.50 \\
\hline France & 6.95 & 90.69 \\
\hline Denmark (KP) & 8.01 & 94.89 \\
\hline Netherlands & 8.58 & 89.41 \\
\hline Sweden & 9.21 & 96.84 \\
\hline Spain & 9.34 & 79.95 \\
\hline Austria & 9.48 & 91.58 \\
\hline Portugal & 9.48 & 83.29 \\
\hline Hungary & 9.57 & 87.11 \\
\hline Belgium & 9.90 & 90.74 \\
\hline Latvia & 10.00 & 82.29 \\
\hline Estonia & 10.24 & 93.58 \\
\hline UK & 10.41 & 68.53 \\
\hline Lithuania & 10.71 & 98.01 \\
\hline Luxembourg & 11.21 & 82.42 \\
\hline Germany & 11.29 & 124.48 \\
\hline Bulgaria & 11.94 & 104.40 \\
\hline Slovenia & 12.19 & 75.31 \\
\hline average EU-28 & 12.03 & 92.12 \\
\hline Italy & 12.54 & 83.11 \\
\hline Poland & 13.56 & 93.26 \\
\hline Cyprus & 16.00 & 93.42 \\
\hline Greece & 16.00 & 70.80 \\
\hline Slovakia & 16.27 & 112.24 \\
\hline Finland & 17.45 & 109.90 \\
\hline Romania & 17.73 & 129.77 \\
\hline Croatia & 20.00 & 82.84 \\
\hline Czech Republic & 20.00 & 92.24 \\
\hline Malta & - & 80.88 \\
\hline & & \\
\hline & & \\
\hline
\end{tabular}


Table A.2: $\mathrm{N}$ excretion and milk yield of dairy cows in the EU28 (Source: UNFCCC 2014)

\begin{tabular}{|l|l|l|}
\hline & $\begin{array}{l}\text { N excretion } \\
\text { [kg N/cow/year] }\end{array}$ & $\begin{array}{l}\text { milk yield } \\
\text { [kg/cow/year] }\end{array}$ \\
\hline Romania & 53.63 & 3650 \\
\hline Latvia & 70.00 & 5249 \\
\hline Poland & 86.70 & 4993 \\
\hline Ireland & 99.71 & 5183 \\
\hline Bulgaria & 99.89 & 4263 \\
\hline Croatia & 100.00 & 3424 \\
\hline Cyprus & 100.00 & 6330 \\
\hline Slovakia & 100.00 & 6293 \\
\hline Austria & 100.26 & 6418 \\
\hline Hungary & 100.38 & 7128 \\
\hline Lithuania & 101.18 & 5227 \\
\hline Greece & 102.63 & 5752 \\
\hline Luxembourg & 107.89 & 7260 \\
\hline Average EU-28 & 108.07 & 6538 \\
\hline Spain & 110.21 & 7818 \\
\hline Slovenia & 111.22 & 5592 \\
\hline France & 115.16 & 6767 \\
\hline Italy & 116.00 & 6428 \\
\hline Germany & 116.85 & 7278 \\
\hline Portugal & 117.30 & 8176 \\
\hline Estonia & 118.09 & 7526 \\
\hline Belgium & 118.12 & 7507 \\
\hline Netherlands & 122.30 & 8192 \\
\hline UK & 122.56 & 7446 \\
\hline Sweden & 124.22 & 8724 \\
\hline Finland & 129.81 & 8114 \\
\hline Czech Republic & 135.78 & 7413 \\
\hline Denmark (KP) & 138.03 & 8373 \\
\hline Malta & - & - \\
\hline & & \\
\hline & & \\
\hline
\end{tabular}


Table A.3: Triangular probability distribution functions of uncertain parameters. (Mode values used for

baseline calculation)

\begin{tabular}{|c|c|c|c|c|c|}
\hline Stochastic variable & Minimum & Mode & Maximum & $\begin{array}{l}\text { Determination } \\
\text { of minimum \& } \\
\text { maximum } \\
\end{array}$ & Source \\
\hline \multicolumn{6}{|l|}{ Prices } \\
\hline Pork [€/kg] & 1.3 & 1.66 & 2.3 & calc. & \multirow{7}{*}{ Statistics Austria 2014} \\
\hline Milk [€/kg] & 0.31 & 0.37 & 0.48 & calc. & \\
\hline Barley $[€ / \mathrm{kg}]$ & 0.09 & 0.12 & 0.24 & calc. & \\
\hline Wheat $[€ / \mathrm{kg}]$ & 0.09 & 0.12 & 0.25 & calc. & \\
\hline Soybean meal [€/kg] & 0.2 & 0.3 & 0.5 & calc. & \\
\hline Rapeseed meal [€/kg] & 0.18 & 0.27 & 0.51 & calc. & \\
\hline Dairy compound feed [€/kg] & 0.2 & 0.3 & 0.5 & $\begin{array}{l}\text { Assumption: } \\
\text { same as soy }\end{array}$ & \\
\hline Plant oil [€/kg] & 0.6 & 1.2 & 1.8 & $50 \%$ & \multirow{2}{*}{$\begin{array}{l}\text { Landesbetrieb Landwirtschaft } \\
\text { Hessen } 2012\end{array}$} \\
\hline L-Lysine HCL [€/kg] & 1 & 2 & 3 & $50 \%$ & \\
\hline Minerals $[€ / \mathrm{kg}]$ & 0.4425 & 0.885 & 1.3275 & $50 \%$ & \multirow{6}{*}{ AWI 2015} \\
\hline Grass silage REF [€/dt DM] & 4.48 & 8.95 & 17.90 & Factor 2 & \\
\hline Grass silage $\mathrm{S}[€ / \mathrm{dt} \mathrm{DM}]$ & 4.69 & 9.37 & 18.74 & Factor 2 & \\
\hline Hay REF $[€ / d t$ DM] & 4.91 & 9.81 & 19.62 & Factor 2 & \\
\hline Hay $S[€ / d t$ DM] & 5.22 & 10.43 & 20.86 & Factor 2 & \\
\hline Maize silage [€/dt DM] & 4.39 & 8.78 & 17.56 & Factor 2 & \\
\hline $\begin{array}{l}\text { Investment cost phase feeding } \\
\text { [€] }\end{array}$ & 6500 & 7500 & 30000 & & ALB Hessen 2008 \\
\hline $\begin{array}{l}\text { Milk yield REF_milk } \\
{\left[\mathrm{kg} / \text { cow }^{*} \text { year] }\right.}\end{array}$ & 5263 & 6191 & 7120 & $15 \%$ & \multirow{2}{*}{$\begin{array}{l}\text { Calc. based on energy intake } \\
\text { (AWI 2015) }\end{array}$} \\
\hline Milk yield S_milk [kg/cow*year] & 7932 & 9332 & 10732 & $15 \%$ & \\
\hline $\begin{array}{l}\mathrm{N} \text { excretion REF_pig }[\mathrm{kg} \\
\mathrm{N} / \text { fattening pig] }\end{array}$ & 3.28 & 3.86 & 4.44 & $15 \%$ & Umweltbundesamt 2014b \\
\hline $\begin{array}{l}\mathrm{N} \text { excretion S1_pig [kg } \\
\mathrm{N} / \text { fattening pig] }\end{array}$ & 2.80 & 3.29 & 3.79 & $15 \%$ & \multirow{2}{*}{$\begin{array}{l}\text { Calc. based on N_ex pig REF and } \\
\text { protein content of feed }\end{array}$} \\
\hline $\begin{array}{l}\mathrm{N} \text { excretion S2_pig [kg } \\
\mathrm{N} / \text { fattening pig] }\end{array}$ & 2.43 & 2.85 & 3.28 & $15 \%$ & \\
\hline $\begin{array}{l}\mathrm{N} \text { excretion REF_milk [kg } \\
\mathrm{N} / \text { animal*year] }\end{array}$ & 79.05 & 98.82 & 118.58 & $20 \%$ & \multirow{2}{*}{$\begin{array}{l}\text { Calc. based on Gruber et al. } \\
\text { 1999, Spiekers et al. } 2015\end{array}$} \\
\hline $\begin{array}{l}\text { N excretion S_milk [kg } \\
\text { N/animal*year] }\end{array}$ & 95.79 & 119.74 & 143.69 & $20 \%$ & \\
\hline \multicolumn{6}{|l|}{ Emission factors (EF) } \\
\hline \multicolumn{5}{|l|}{$\begin{array}{l}\text { EF animal housing } \mathrm{NH}_{3}\left[\mathrm{~kg} \mathrm{NH}_{3}-\right. \\
\mathrm{N} / \mathrm{kg} \mathrm{Nex}]\end{array}$} & \multirow{11}{*}{$\begin{array}{l}\text { European Environment Agency } \\
\text { (EEA) 2013, IPCC 2006b, 2006a; } \\
\text { Umweltbundesamt 2014a, } \\
\text { 2014b; Winiwarter and Rypdal } \\
2001\end{array}$} \\
\hline Pig & 0.09 & 0.15 & 0.21 & $40 \%$ & \\
\hline Dairy & 0.07 & 0.12 & 0.17 & $40 \%$ & \\
\hline \multicolumn{5}{|l|}{$\begin{array}{l}\text { EF manure storage } \mathrm{NH}_{3}[\mathrm{~kg} \\
\mathrm{NH}_{3}-\mathrm{N} / \mathrm{kg} \text { TAN] }\end{array}$} & \\
\hline Pig & 0.07 & 0.12 & 0.17 & $40 \%$ & \\
\hline Dairy & 0.09 & 0.15 & 0.21 & $40 \%$ & \\
\hline $\begin{array}{l}\text { EF manure management } \mathrm{N}_{2} \mathrm{O} \\
{\left[\mathrm{kg} \mathrm{N} \mathrm{N}_{2} \mathrm{O}-\mathrm{N} / \mathrm{kg} \mathrm{Nex}\right]}\end{array}$ & 0.0005 & 0.001 & 0.002 & Factor 2 & \\
\hline \multicolumn{5}{|l|}{$\begin{array}{l}\text { EF total from manure } \\
\text { management NO }[\mathrm{kg} \\
\text { NO/year*AAP] }\end{array}$} & \\
\hline Pig & 0.0005 & 0.001 & 0.002 & Factor 2 & \\
\hline Dairy & 0.0035 & 0.007 & 0.014 & Factor 2 & \\
\hline $\begin{array}{l}\text { EF broadcast spreading liquid } \\
\text { manure }\left[\mathrm{kg} \mathrm{NH} \mathrm{NH}_{3}-\mathrm{N} / \mathrm{kg} \text { TAN] }\right.\end{array}$ & & & & & \\
\hline
\end{tabular}




\begin{tabular}{|l|l|l|l|l|}
\hline Pig & 0.15 & 0.25 & 0.35 & $40 \%$ \\
\hline Dairy & 0.3 & 0.5 & 0.7 & $40 \%$ \\
\hline $\begin{array}{l}\text { EF manure spreading NO [kg } \\
\text { NO-N/kg N in manure] }\end{array}$ & 0.005 & 0.01 & 0.02 & Factor 2 \\
\hline $\begin{array}{l}\text { EF direct emissions from soils } \\
\mathrm{N}_{2} \mathrm{O}\left[\mathrm{t} \mathrm{N} \mathrm{N}_{2} \mathrm{O}-\mathrm{N} / \mathrm{tN} \text { applied] }\right.\end{array}$ & 0.00625 & 0.0125 & 0.025 & Factor 2 \\
\hline
\end{tabular}


Table A.4: Correlations used for Monte Carlo simulation

\begin{tabular}{|l|l|l|l|l|l|}
\hline & Barley & Soy & Wheat & $\begin{array}{l}\text { Plantoil } \\
\text { \& rape }\end{array}$ & Milk \\
\hline Barley & 1 & & & & \\
\hline Soy & 0.288 & 1 & & & \\
\hline Wheat & 0.899 & 0.419 & 1 & & \\
\hline Plantoil \& rape & 0.668 & 0.639 & 0.71 & 1 & \\
\hline Milk & 0.366 & - & - & - & 1 \\
\hline & & & & & \\
\hline
\end{tabular}

\section{Forage provision cost}

\begin{tabular}{|l|l|l|l|l|l|}
\hline & $\begin{array}{l}\text { Grass } \\
\text { REF_milk }\end{array}$ & $\begin{array}{l}\text { Grass } \\
\text { S_milk }\end{array}$ & $\begin{array}{l}\text { Hay } \\
\text { REF_milk }\end{array}$ & $\begin{array}{l}\text { Hay } \\
\text { S_milk }\end{array}$ & \\
\hline Grass REF_milk & 1 & & & & \\
\hline Grass S_milk & 1 & 1 & & & \\
\hline Hay REF_milk & 1 & 1 & 1 & & \\
\hline Hay S_milk & 1 & 1 & 1 & 1 & \\
\hline & & & & & \\
\hline
\end{tabular}

Milk yields

\begin{tabular}{|c|c|c|c|c|c|}
\hline & $\begin{array}{l}\text { Milk } \\
\text { yield } \\
\text { REF_milk }\end{array}$ & $\begin{array}{l}\text { Milk } \\
\text { yield } \\
\text { S_milk }\end{array}$ & & & \\
\hline $\begin{array}{l}\text { Milk yield } \\
\text { REF_milk }\end{array}$ & 1 & & & & \\
\hline Milk yield S_milk & 1 & 1 & & & \\
\hline \multicolumn{6}{|l|}{$\mathbf{N}$ excretion } \\
\hline & $\begin{array}{l}\text { N_ex } \\
\text { REF_pig }\end{array}$ & $\begin{array}{l}\text { N_ex } \\
\text { S1_pig }\end{array}$ & $\begin{array}{l}\text { N_ex } \\
\text { S2_pig }\end{array}$ & $\begin{array}{l}\text { N_ex } \\
\text { REF_milk }\end{array}$ & $\begin{array}{l}\text { N_ex } \\
\text { S_milk }\end{array}$ \\
\hline N_ex REF_pig & 1 & & & & \\
\hline N_ex S1_pig & 1 & 1 & & & \\
\hline N_ex S2_pig & 1 & 1 & 1 & & \\
\hline N_ex REF_milk & - & - & - & 1 & \\
\hline N_ex S_milk & - & - & - & 1 & 1 \\
\hline
\end{tabular}




\section{Figure captions}

1

6

Fig. 1 Cumulative probabilities of partial gross margins. a) pig (€/kg meat). Solid line: REF_pig, dotted line: S1_pig, dashed line: S2_pig; b) dairy (€/kg milk). Solid line: REF_milk, dotted line: S_milk. The vertical line in both $a$ and $b$ marks the baseline value from REF (considering no uncertainties)

794 Fig. 2 Cumulative probabilities of $\mathrm{N}$ losses, including $\mathrm{NH}_{3}, \mathrm{~N}_{2} \mathrm{O}$ and NO. a) pig (kg N/kg meat). Solid 795 line: REF_pig, dotted line: S1_pig, dashed line: S2_pig; b) dairy (kg N/kg milk). Solid line: REF_milk, 796 dotted line: S_milk. The vertical line in both a and b marks the baseline value from REF (considering 797 no uncertainties)

Fig. 3 Cumulative probabilities of abatement costs for all analysed measures ( $€ / \mathrm{kg} N)$. Dashed line: S1_pig, dotted line: S2_pig, solid line: S_milk 

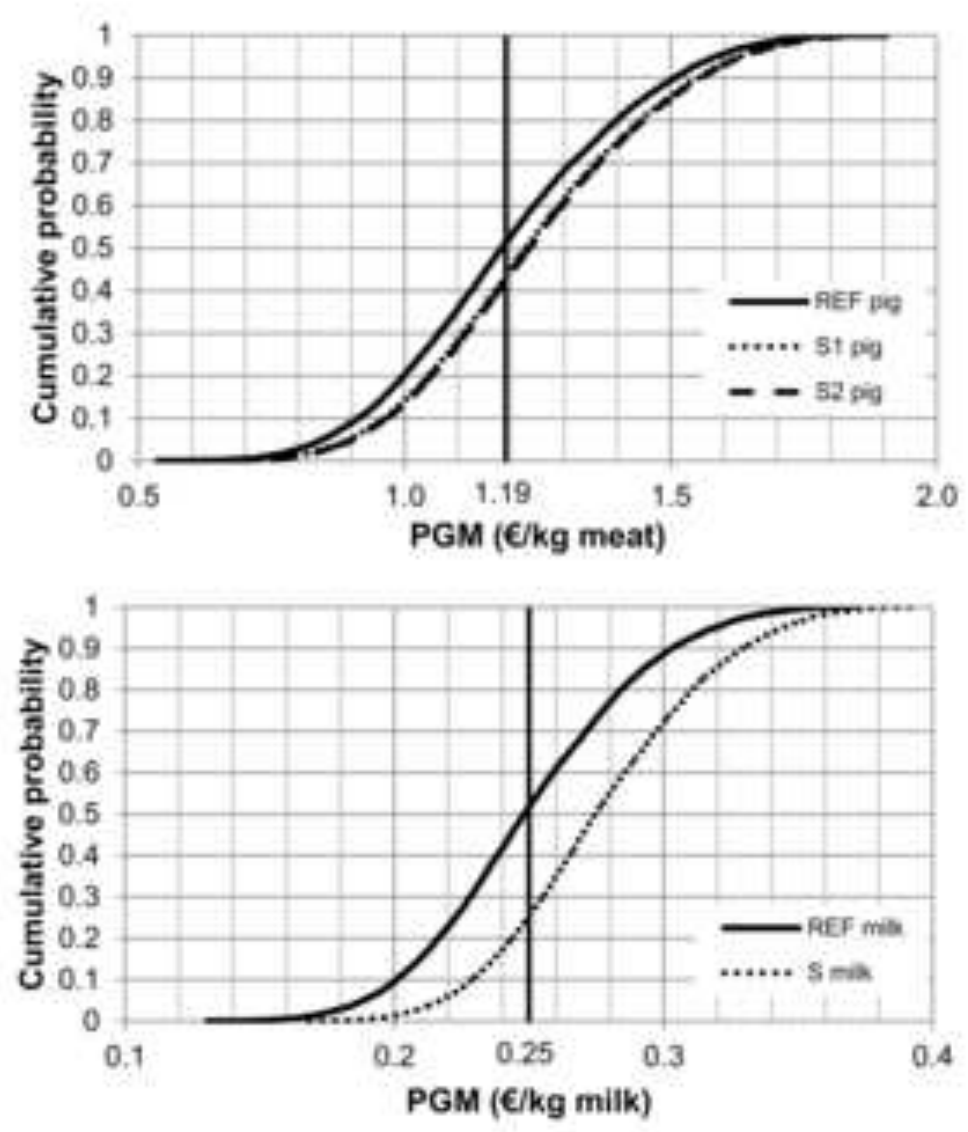

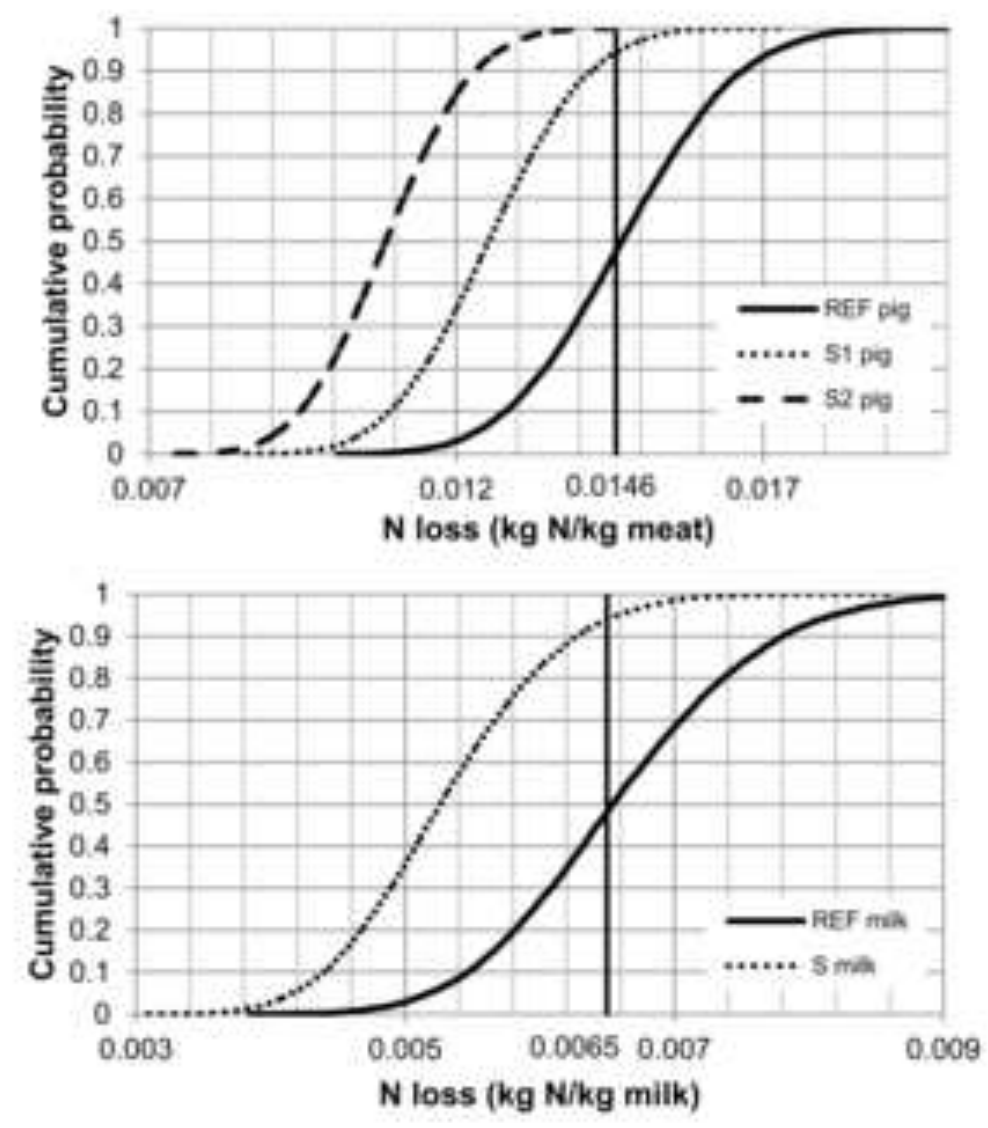


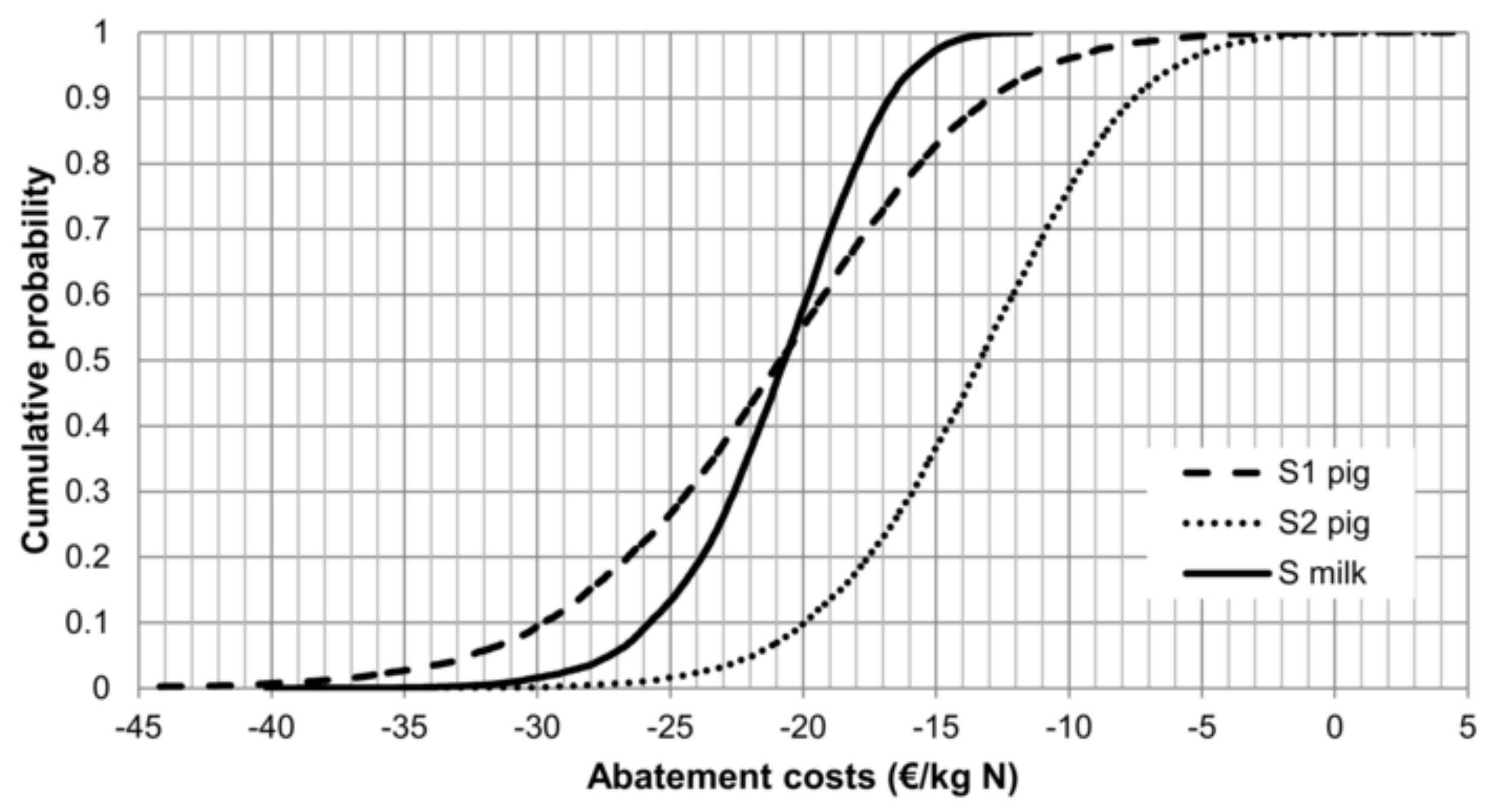

